\title{
Focal Pancreatic Lesions: Role of Contrast-Enhanced Ultrasonography
}

\author{
Tommaso Vincenzo Bartolotta ${ }^{1,2}{ }^{\mathbb{D}}$, Angelo Randazzo ${ }^{1}$ (D), Eleonora Bruno ${ }^{1}$, Pierpaolo Alongi ${ }^{2,3, *(D)}$ and \\ Adele Taibbi ${ }^{1}$
}

check for updates

Citation: Bartolotta, T.V.; Randazzo,

A.; Bruno, E.; Alongi, P.; Taibbi, A.

Focal Pancreatic Lesions: Role of

Contrast-Enhanced Ultrasonography.

Diagnostics 2021, 11, 957.

https://doi.org/10.3390/

diagnostics 11060957

Academic Editor: Keiji Hanada

Received: 19 April 2021

Accepted: 25 May 2021

Published: 26 May 2021

Publisher's Note: MDPI stays neutral with regard to jurisdictional claims in published maps and institutional affiliations.

Copyright: (C) 2021 by the authors. Licensee MDPI, Basel, Switzerland. This article is an open access article distributed under the terms and conditions of the Creative Commons Attribution (CC BY) license (https:/ / creativecommons.org/licenses/by/ $4.0 /)$.
1 BiND Department: Biomedicine, Neuroscience and Advanced Diagnostic, University of Palermo, Via Del Vespro, 129, 90127 Palermo, Italy; tommasovincenzo.bartolotta@unipa.it (T.V.B.); angelo.randazzo.90@gmail.com (A.R.); elebru.91@gmail.com (E.B.); taibbiadele@hotmail.com (A.T.)

2 Department of Radiology, Fondazione Istituto Giuseppe Giglio Ct.da Pietrapollastra, Via Pisciotto, Cefalù, 90015 Palermo, Italy

3 Unit of Nuclear Medicine, Fondazione Istituto Giuseppe Giglio Ct.da Pietrapollastra, Via Pisciotto, Cefalù, 90015 Palermo, Italy

* Correspondence: alongi.pierpaolo@gmail.com

\begin{abstract}
The introduction of contrast-enhanced ultrasonography (CEUS) has led to a significant improvement in the diagnostic accuracy of ultrasound in the characterization of a pancreatic mass. CEUS, by using a blood pool contrast agent, can provide dynamic information concerning macro- and micro-circulation of focal lesions and of normal parenchyma, without the use of ionizing radiation. On the basis of personal experience and literature data, the purpose of this article is to describe and discuss CEUS imaging findings of the main solid and cystic pancreatic lesions with varying prevalence.
\end{abstract}

Keywords: contrast-enhanced ultrasound; pancreas; diagnostic imaging

\section{Introduction}

Contrast-enhanced Ultrasound (CEUS) allows non-invasive assessment of normal and pathologic perfusion of various organs in real time throughout the vascular phase, without the use of ionizing radiation and with a much higher temporal resolution than Computed Tomography (CT) and Magnetic Resonance Imaging (MRI) [? ? ? ]. CEUS examination is performed by intravenously injecting Ultrasounds contrast agents (USCAs) consisting of flexible shells (e.g., phospholipids, liposomes) presenting a radius ranging from 1 to $10 \mu \mathrm{m}$, containing low solubility gases (e.g., perfluoro-propane, perfluorocarbon, or sulfur hexafluoride) [? ]. USCAs microbubbles pass through the lung capillary bed and remain confined within the intravascular space. Approximately $20 \mathrm{~min}$ after the injection, the USCAs are completely eliminated: the gas diffuses into the blood and is then exhaled via the pulmonary route, while the shell components are metabolized by the liver or filtered by the kidney [? ].

CEUS is safe and well tolerated by patients with hepatic or renal failure, renal obstruction, or chronic obstructive pulmonary disease. In a retrospective analysis of more than 23,000 applications of a sulfur-hexafluoride based contrast agent, 29 cases of mild adverse events were reported and only two cases of anaphylactoid reactions resolved completely without permanent damage [? ]. Hence, there is no need of laboratory tests for assessing renal function before administering USCAs.

Contrast-enhanced ultrasonography (CEUS) is not recommended for the detection of a focal pancreatic mass, but it is deemed helpful in the differentiation of lesions such as adenocarcinoma, islet cell tumor, serous cystadenoma or pseudocyst, thus allowing a better patient clinical management [? ].

After the detection of a pancreatic mass at US, CEUS should be performed for best accuracy of first line examination before CT and MRI [? ]. 
Furthermore CEUS could reduce the number of false-positive results on MRI for visualization of septa and nodules in pancreatic cystic lesions, so CEUS can be considered a complementary examination for the characterization of cystic pancreatic masses and their follow-up after the initial comprehensive imaging assessment, decreasing the frequency of $\mathrm{CT}$ and MRI examinations, limiting radiation and expense [? ].

The European Federation of Societies for Ultrasound in Medicine and Biology (EFSUMB) guidelines suggest studying focal pancreatic lesions with CEUS in order to evaluate a pancreatic mass (Table ??), [? ].

Table 1. EFSUMB Recommendation for studying focal pancreatic lesion on CEUS.

EFSUMB Recommendation for CEUS

- Characterization of ductal adenocarcinoma for lesions showed on US

- Differential diagnosis between ductal adenocarcinoma and neuroendocrine tumors

- Differential diagnosis between pseudocysts and cystic tumors

- Differentiation of vascular (solid) from avascular (liquid/necrotic) components of a lesion

- Defining the dimensions and margins of a lesion, including its relationship with adjacent vessels

- Characterization of acute necrotizing pancreatitis

- Improving accuracy of percutaneous ultrasound-guided pancreatic procedures

- Diagnosis of cystic lesions that are indeterminate on CT

On the basis of personal experience and literature data, CEUS characteristics of the main solid and cystic pancreatic lesions will be presented and discussed.

\section{CEUS Technique}

CEUS, by using a blood pool contrast agent, can provide dynamic information concerning macro- and micro-circulation of focal lesions and of normal parenchyma. A baseline survey examination with multifrequency convex array probes, including a color/power and pulsed Doppler analysis, was always performed in order to choose the best acoustic window and plane with which to image the lesion, followed by harmonic microbubble specific imaging. The Ultrasound (US) contrast agent, that in our examples used a sulfur hexafluoride-filled microbubble-based contrast agent (SonoVue, Bracco, Milan, Italy), was injected intravenously, followed by 5-10 mL of normal saline flush using a 20- or 22-gauge peripheral intravenous cannula. In order to minimize microbubble disruption, a low framerate and a low mechanical index (MI) were used for real-time imaging. Digital cine-loops were registered both during baseline and post-contrast US scanning in the contrastographic phases (early arterial, arterial, pancreatic, portal and late phases). After completion of the pancreatic study, the liver should be assessed in the late phase, exploiting the same contrast injection, in searching for metastases [? ].

\section{Pancreatic Solid Lesions}

\subsection{Pancreatic Ductal Adenocarcinoma}

Pancreatic cancer is the seventh leading cause of cancer death worldwide, with a total number of deaths in 2020 amounting to 466,003 [? ]. Pancreatic ductal adenocarcinoma (PDAC) is the most common primary malignancy of the pancreas, accounting for $85-95 \%$ of all pancreatic malignancies [? ]. PDAC prognosis is poor, with a 1-year survival rate of less than $20 \%$ and a 5 -year survival rate of less than $5 \%$. About $70 \%$ of PDACs arise in the pancreatic head, while $30 \%$ are located in the body/tail. PDAC originates from pancreatic ductal epithelia, with dense cellularity, sparse vascularity, intense stromal desmoplasia and variable necrosis. There are three recognized precursors of invasive PDAC: pancreatic intraepithelial neoplasia (PanIN), intraductal papillary mucinous neoplasm (IPMN) and mucinous cystic neoplasm (MCN) [? ]. Adenocarcinoma appears as an illdefined, heterogeneous hypoechoic mass at US (Figure ??A). Pathologic features of PDAC affect imaging findings. In particular, at CEUS PDAC is typically hypo-enhancing in all 
phases, because of the desmoplastic reaction with low vascular density (Figure ??B) [? ]. On the basis of the hypo-vascular pattern, a multicenter study has reported an accuracy of $87.8 \%$ in the characterization of PDAC at CEUS [? ]. A recent metanalysis showed a pooled estimate of CEUS sensitivity and specificity in the diagnosis of PDAC of 0.89 (95\% CI 0.85-0.92) and 0.84 (95\% CI 0.77-0.89), respectively [? ]. Of note, in a study encompassing 133 patients, CEUS sensitivity in diagnosing pancreatic ductal adenocarcinoma $(86.47 \%)$ was reported to be not statistically different from that of multidetector CT (83.58\%), $p$ $=0.523$ [? ]. On this basis international guidelines state that in solid pancreatic lesions detected on ultrasound, CEUS can be used to reliably characterize ductal adenocarcinoma [? ].

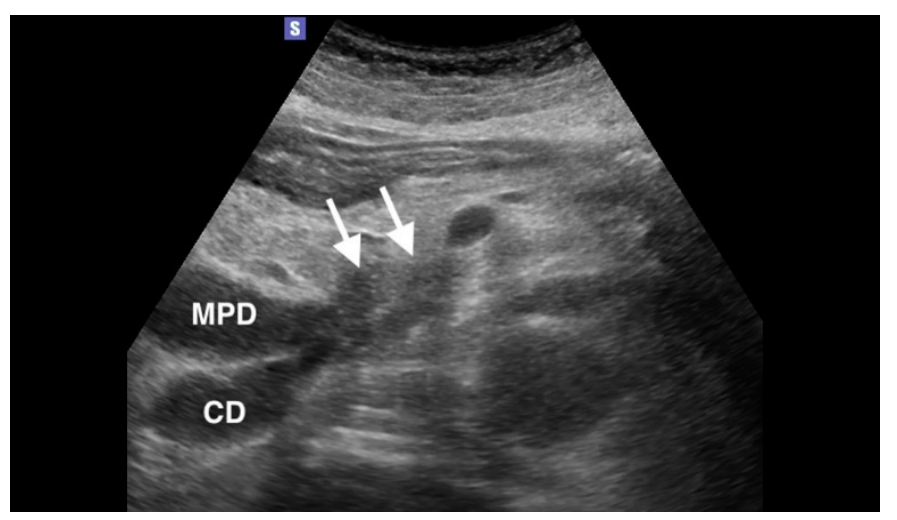

(A)

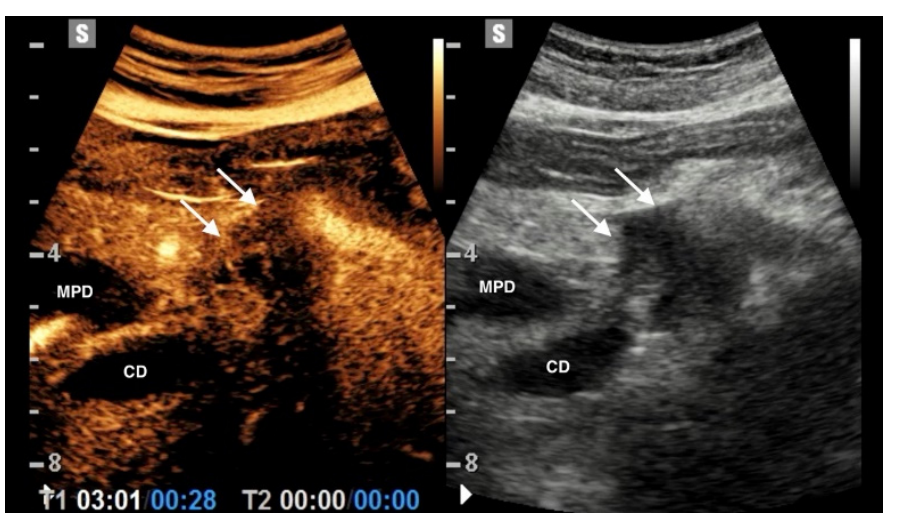

(B)

Figure 1. Pancreatic adenocarcinoma in an 89 years old woman. (A) B mode Ultrasonography depicts a $3.5 \mathrm{~cm}$ heterogenous hypoechoic mass (arrows) in the pancreatic head: severe dilation of the main pancreatic duct (MPD) and cystic duct (CD) is also appreciable. (B) On CEUS, in the arterial phase (28 s after the injection of c.a.) the mass is hypoechoic in comparison with the adjacent pancreatic parenchyma (arrows).

CEUS has been demonstrated to be beneficial for liver staging and to assess relationship with adjacent vessels [? ? ]. This information is of paramount importance for preoperative assessment of the resectability of PDAC [? ]. When target lesions are not well localized on B-mode ultrasound, CEUS can effectively guide and control percutaneous pancreas biopsies with a percentage of satisfactory percutaneous biopsy as high as $96 \%$, lowering the incidence of complications [? ]. The inherent exquisite sensitivity of CEUS in depicting micro-vascularity can be exploited for assessing vascular changes during or after chemotherapy [? ].

\subsection{Pancreatic Neuroendocrine Tumors}

Pancreatic neuroendocrine tumors (pNET) represent $1-2 \%$ of all pancreatic neoplasms, and about $7 \%$ of all NETs [? ]. pNETs were previously deemed to originate from the islets of Langerhans (namely, islet cell tumors) but nowadays these tumors are considered to originate from pluripotential stem cells in ductal epithelium [? ].

Most pNETs are sporadic, while $10-30 \%$ of these occur within hereditary syndrome, such as Multiple Endocrine Neoplasia type I, type IV, neurofibromatosis type I, von Hippel-Lindau disease and tuberous sclerosis. pNETs can be classified into functional and non-functional tumors. About $10 \%$ of pNETs are functional with symptoms related to the type of hormone secretion; in this group, insulinomas are the most common (30-40\%), followed by gastrinomas $(16-30 \%)$, glucagonomas $(<10 \%)$, VIPomas $(<10 \%)$ and somatostatin-omas $(<5 \%)$ [? ].

About $60-70 \%$ of patients with pNETs have a metastatic disease at diagnosis with differences based on histology. Liver metastases are present in more than $50 \%$ of patients, strongly influencing the prognosis [? ]. 
On CEUS, pNETs usually appear as hyper-enhancing lesions in the arterial phase, either homogeneous or heterogeneous, owing to their abundant arterialization (Figure ??) [? ]. The presence of heterogeneous enhancement is often related to the presence of necrotic areas within the lesion, especially in larger tumors.

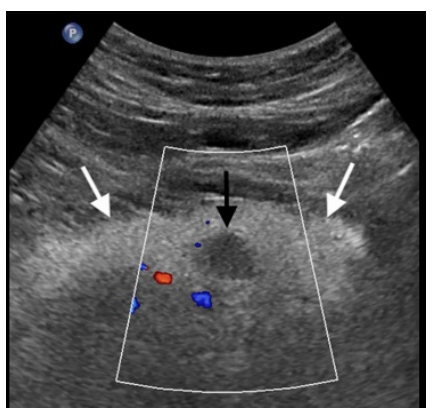

(A)

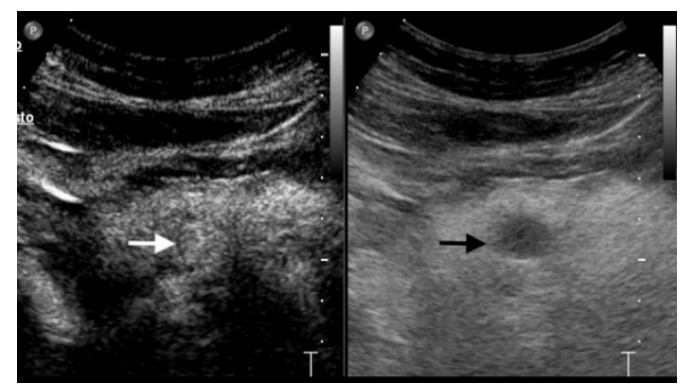

(B)

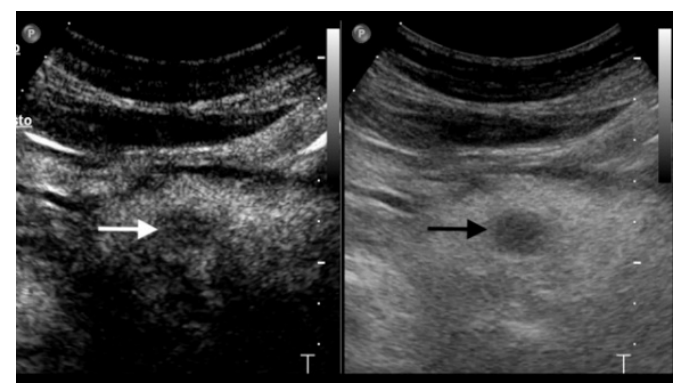

(C)

Figure 2. Pancreatic NET: insulinoma. (A) Color Doppler Ultrasonography (white box) depicts lack of vascularity within a $1.5 \mathrm{~cm}$ hypoechoic mass (black arrow) in the pancreatic body (white arrows). (B) On CEUS, in the arterial phase (19 s after the injection of c.a.), the mass is slightly hyperechoic in comparison with the adjacent pancreatic parenchyma (arrow), indicating rich vascularity. (C) On CEUS, in the late phase (120 s after the injection of c.a.), the mass is hypoechoic in comparison with the adjacent pancreatic parenchyma (arrow), indicating "wash-out".

According to the European Federation of Societies of Ultrasound in Medicine and Biology (EFSUMB) and the European Neuroendocrine Tumor Society (ENETS) consensus guidelines, CEUS can be used to distinguish between pancreatic ductal adenocarcinoma and neuroendocrine tumors (Table ??) [? ? ].

Table 2. Features and enhancing pattern of focal pancreatic lesions in CEUS.

\begin{tabular}{|c|c|c|c|c|c|c|}
\hline & $\begin{array}{l}\text { Hypo-Vascular } \\
\text { Heterogeneous }\end{array}$ & $\begin{array}{l}\text { Hyper-Vascular } \\
\text { Heterogeneous }\end{array}$ & $\begin{array}{l}\text { Iso-Vascular } \\
\text { Heterogeneous }\end{array}$ & $\begin{array}{l}\text { Hyper-Vascular } \\
\text { Homogeneous }\end{array}$ & $\begin{array}{l}\text { Hypo-Vascular } \\
\text { Homogeneous }\end{array}$ & $\begin{array}{l}\text { Iso-Vascular } \\
\text { Homogeneous }\end{array}$ \\
\hline Solid & Adenocarcinoma & $\begin{array}{l}\text { Neuroendocrine } \\
\text { tumors } \\
\text { Adenocarcinoma }\end{array}$ & Adenocarcinoma & $\begin{array}{l}\text { Neuroendocrine } \\
\text { tumors } \\
\text { Adenocarcinoma }\end{array}$ & Adenocarcinoma & Adenocarcinoma \\
\hline Cystic simple & - & $\begin{array}{l}\text { Neuroendocrine } \\
\text { tumors }\end{array}$ & $\begin{array}{l}\text { Mucinous } \\
\text { cystadenoma }\end{array}$ & $\begin{array}{l}\text { Neuroendocrine } \\
\text { tumors }\end{array}$ & $\begin{array}{l}\text { Pseudocyst } \\
\text { IPMN }^{1} \\
\text { Serous } \\
\text { cystadenoma }\end{array}$ & $\begin{array}{l}\text { Pseudocyst } \\
\text { IPMN } \\
\text { Serous } \\
\text { cystadenoma }\end{array}$ \\
\hline Cystic with septa & Adenocarcinoma & - & $\begin{array}{l}\text { Adenocarcinoma } \\
\text { Mucinous } \\
\text { cystadenoma }\end{array}$ & - & $\begin{array}{c}\text { Adenocarcinoma } \\
\text { IPMN } \\
\text { Serous } \\
\text { cystadenoma }\end{array}$ & $\begin{array}{c}\text { Adenocarcinoma } \\
\text { IPMN } \\
\text { Serous } \\
\text { cystadenoma }\end{array}$ \\
\hline $\begin{array}{l}\text { Cystic with } \\
\text { nodules }\end{array}$ & $\begin{array}{c}\text { Cystadenocarcinoma } \\
\text { Mucinous } \\
\text { cystadenoma }\end{array}$ & $\begin{array}{c}\text { Cystadenocarcinoma } \\
\text { Neuroendocrine } \\
\text { tumors }\end{array}$ & $\begin{array}{c}\text { Cystadenocarcinoma } \\
\text { Mucinous } \\
\text { cystadenoma }\end{array}$ & $\begin{array}{l}\text { Neuroendocrine } \\
\text { tumors }\end{array}$ & $\begin{array}{c}\text { Cystadenocarcinoma } \\
\text { Mucinous } \\
\text { cystadenoma }\end{array}$ & $\begin{array}{c}\text { Mucinous } \\
\text { cystadenoma }\end{array}$ \\
\hline $\begin{array}{c}\text { Cystic with thick } \\
\text { wall }\end{array}$ & $\begin{array}{c}\text { IPMN } \\
\text { Mucinous } \\
\text { cystadenoma } \\
\text { Adenocarcinoma }\end{array}$ & $\begin{array}{l}\text { Neuroendocrine } \\
\text { tumors }\end{array}$ & $\begin{array}{c}\text { IPMN } \\
\text { Pseudocyst } \\
\text { Serous } \\
\text { cystadenoma } \\
\text { Mucinous } \\
\text { cystadenoma } \\
\end{array}$ & $\begin{array}{l}\begin{array}{c}\text { Neuroendocrine } \\
\text { tumors }\end{array} \\
\text { Adenocarcinoma }\end{array}$ & $\begin{array}{c}\text { IPMN } \\
\text { Pseudocyst } \\
\text { Serous } \\
\text { cystadenoma } \\
\text { Mucinous } \\
\text { cystadenoma } \\
\end{array}$ & $\begin{array}{c}\text { IPMN } \\
\text { Pseudocyst } \\
\text { Serous } \\
\text { cystadenoma } \\
\text { Mucinous } \\
\text { cystadenoma } \\
\end{array}$ \\
\hline $\begin{array}{l}\text { Cystic with septa, } \\
\text { nodules and thick } \\
\text { wall }\end{array}$ & $\begin{array}{c}\text { IPMN } \\
\text { Adenocarcinoma } \\
\text { Cystadenocarcinoma }\end{array}$ & $\begin{array}{l}\text { Neuroendocrine } \\
\text { tumors }\end{array}$ & $\begin{array}{c}\text { IPMN } \\
\text { Adenocarcinoma } \\
\text { Cystadenocarcinoma }\end{array}$ & $\begin{array}{l}\text { Neuroendocrine } \\
\text { tumors }\end{array}$ & $\begin{array}{c}\text { IPMN } \\
\text { Adenocarcinoma } \\
\text { Cystadenocarcinoma }\end{array}$ & $\begin{array}{c}\text { IPMN } \\
\text { Adenocarcinoma }\end{array}$ \\
\hline
\end{tabular}

${ }^{1}$ IPMN: Intraductal papillary mucinous neoplasms. 


\section{Neoplastic Cystic Lesions}

Pancreatic cystic lesions (PCLs) encompass a broad spectrum of entities with different malignant potential. PCLs can be categorized into neoplastic and nonneoplastic. Common cystic neoplasms include intraductal papillary mucinous neoplasm (IPMN), mucinous cysto-adenoma and serous cysto-adenoma. Uncommon cystic neoplasms are represented by solid pseudopapillary tumor, neuroendocrine cystic tumor and cystic adenocarcinoma.

IPMNs, mucinous cystic neoplasms (MCNs), and solid pseudopapillary neoplasms (SPNs) can undergo malignant transformation, whereas cystic pancreatic neuroendocrine tumors (cNETs) already harbor metastatic potential. On the other hand, nonneoplastic PCLs, such as pseudocysts, lymphoepithelial cysts, and retention cysts, behave indolently and almost never progress into malignancy [? ]. Therefore, the evaluation of a PCL should lead to the differentiation between benign and malignant nature of the lesion, thus prompting the correct management strategy [?].

PCLs are an increasingly recognized clinical entity: in asymptomatic patients, up to $2.5 \%$ are found to have pancreatic cysts, a number that increases to $10 \%$ of patients older than 70 years. The frequency of incidentally detected PCLs in asymptomatic patients is increasing and is currently estimated to represent more than $60 \%$ of all detected cystic lesions in the pancreas [? ]. Prevalence, size and number of lesions per patient increase with age but the widespread use of cross-sectional imaging has led to a surge of PCL prevalence. An almost 8\% linear increase in prevalence between 1995 and 2010 has been reported, along with a simultaneous decrease in cyst size from a mean of $2.4 \mathrm{~cm}$ between the years 1995 and 2005 to a mean of $1.6 \mathrm{~cm}$ between 2005 and 2010 [? ]. Incidental PCLs are discovered in $1.2-2.6 \%$ of CT scans, $2.4-19.9 \%$ of MRI scans and up to $45 \%$ in MRCP studies [? ? ? ? ].

The surge of incidentally detected PCLs by cross-sectional imaging has led to the definition "disease of technology" and to the clinical conundrum of a proper management. Several international associations have prompted white papers, recommendations and guidelines to manage PCLs, in terms of diagnosis, imaging surveillance, performance, and cost-effectiveness, but there is no definitive strategy for the differentiation between the various types of PCN and for neoplastic grading. Yet, given the low rate of malignant transformation of pancreatic cysts $(0.12 \%$ annually), a "low intensity" surveillance strategy may be considered appropriate for PCLs without high-risk or worrisome features at imaging (Table ??) [? ? ? ? ].

Table 3. Pancreatic Cystic Lesions: Imaging features in favor of malignancy.

\begin{tabular}{ll}
\hline Pancreatic Cystic Lesions: Imaging Features in Favor of Malignancy \\
\hline - "High-risk stigmata" \\
$0 \quad$ main pancreatic duct diameter of at least $10 \mathrm{~mm}$ \\
$0 \quad$ obstructive jaundice associated with a cyst in the pancreatic head \\
- $\quad$ solid enhancing nodular lesion within the cyst \\
$0 \quad$ cyst $\geq 3 \mathrm{~cm}$ \\
$0 \quad$ thick or contrast-enhancing cyst walls \\
$0 \quad$ main pancreatic duct diameter of 5-9 mm \\
\hline
\end{tabular}

\subsection{Mucinous Cystic Neoplasms}

Cystic mucin-producing pancreatic neoplasms are classified by the World Health Organization (WHO) into two distinct entities, based on the presence of ovarian stroma: intraductal papillary mucinous neoplasms (IPMNs) and mucinous cystic neoplasms (MCNs) [? ]. 


\subsubsection{IPMN}

Described for the first time in 1982 by Ohhashi K et al. as neoplasm with mucin hyperproduction, dilation of the duct of Wirsung and protruding papilla (the Ohhashi triad), intraductal papillary mucinous neoplasms (IPMNs) were more specifically described in 1996 by the WHO as: "neoplasm covered with columnar cells containing high mucin with or without papillary projections, involving the main pancreatic duct and/or secondary ducts without an ovarian stroma".

There are four subtypes of IPMN: Gastric, Intestinal, Oncocitic, and Pancreatobiliary. All subtypes progress via the classic adenoma-carcinoma sequence [? ]. IPMNs communicate with the ductal system and can be further classified into main duct (MD), branch duct (BD), or mixed type IPMNs [? ]. This latter classification is of clinical relevance, considering that in terms of malignant potential, MD-IPMNs and mixed IPMNs have greater risk (36-100\%) compared to BD-IPMNs (11-30\%) [? ].

The majority $(70 \%)$ of IPMNs present in the head of the pancreas, but $20 \%$ present in the body or tail. Unlike other common PCNs, which all present as solitary cysts, IPMNs can be solitary or multifocal. In the MD-IPMN, US may demonstrate involvement of the main pancreatic duct when it is dilated, and the IPMN as a hypo-anecoic mass downstream of the main pancreatic duct dilatation [? ]. Dilatation $>1 \mathrm{~cm}$ of main duct is suggestive for IPMN of main duct; a pancreatic mucinous cyst communicating with the pancreatic duct without main duct dilation is suggestive for IPMN of branch duct [? ]. Unfortunately, neither US nor CEUS are able to effectively demonstrate communication with the ductal system, which is essential for the final diagnosis of branch duct IPMN. On the other hand, CEUS can easily demonstrate the presence of vascularized mural nodules and tumoral vegetations within a pancreatic cyst and differentiate viable tumoral tissue from avascular mucin plug areas [? ? ]. For this purpose, D'Onofrio et al. showed that there are no significant differences in diagnostic accuracy between CEUS and MRI in the identification of septa and nodules [?].

The differential diagnosis of these cystic lesions ranges from benign to potentially or truly malignant lesions. The most common are considered benign, particularly those that are small in size, but they have the potential to become malignant. Size of cyst $>3 \mathrm{~cm}$, solid component associated with the cyst, and dilated pancreatic duct are the main imaging features of pancreatic cysts predictive of risk of malignancy according to the American Gastroenterological Association guidelines [? ]. Some cystic lesions present similar morphologic features, which make preoperative imaging diagnosis difficult. CEUS's capability to detect septa and nodules can contribute to the differentiation of a cystic neoplasm from nontumoral cyst, as well as the determination of their possible malignant potential (Figure ??).

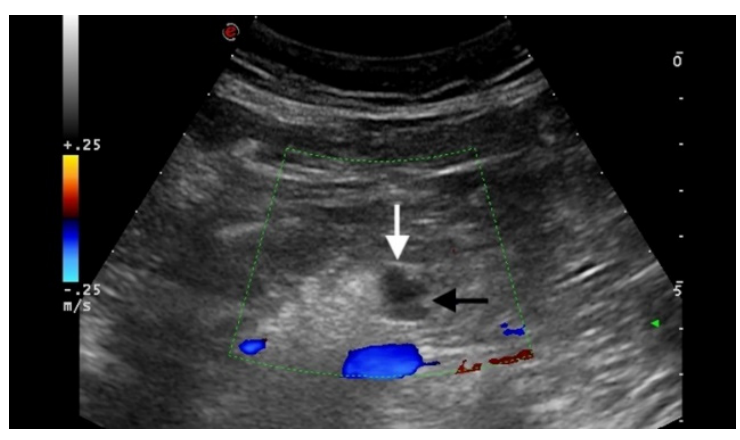

(A)

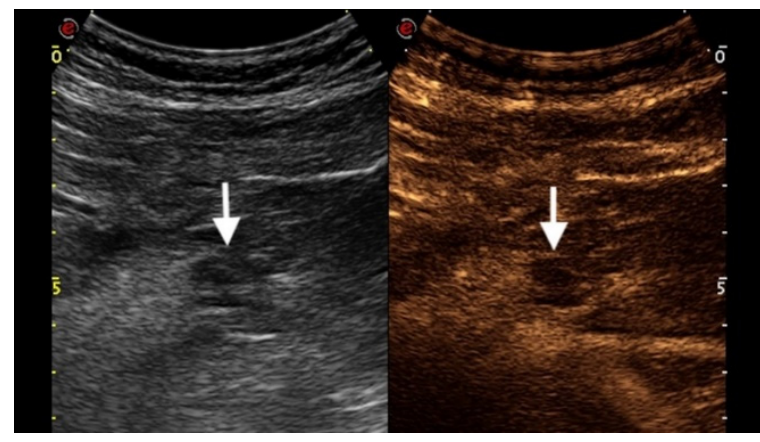

(B)

Figure 3. Branch duct IPMN. (A) Color Doppler Ultrasonography (dotted box) depicts lack of vascularity within a $1 \mathrm{~cm}$ anechoic cystic mass (white arrow) in the pancreatic body. A tiny septum is also appreciable within the lesion (black arrow). (B) On CEUS the lesion shows lack of vascularity throughout the different phases, as well as the internal septum (arrows). 


\subsection{2. $\mathrm{MCNs}$}

Mucinous cystic neoplasms (MCNs) represent about 10\% of all PCLs and include mucinous neoplasms with low-grade dysplasia (MCN) and mucinous cystadenocarcinoma. MCNs occur almost exclusively in middle-aged females and the median age of diagnosis is mid-to-late 40s [? ]. They are usually solitary and are located in the tail and body of the pancreas (90-95\%) [? ]. MCNs are usually large, septated, thick-walled mucinous uni- or oligo-locular cysts that lack communication with the ductal system and occur in middle-aged women. The most characteristic histological finding in MCNs is the presence of a unique ovarian-type stroma not found in other pancreatic neoplasms [? ]. MCNs may show peripheral calcifications [? ]. Increased cystic fluid Carcino-Embryogenic Antigen (CEA) level can be helpful in discerning MCNs from other non-mucinous cystic lesions.

At imaging, including ultrasonography, MCNs usually show round morphology, sharp margin, thick wall, septa, and fluid content, often particulate. The presence of mural nodules and peripheral calcifications are imaging findings in favor of mucinous cystoadeno-carcinoma. US may depict a uni- or oligolocular cystic mass with mural or septal nodules and irregular thickening of the cystic wall [? ]. CEUS may depict enhancement of septa, nodules and cystic wall, during early pancreatic phase and hypo-enhancement during the delayed phase, thus indicating a malignant lesion as cystadenocarcinoma [? ]. For this purpose, CEUS compares favorably with MRI in displaying the inner structure of these cystic neoplasms and can provide useful clues for diagnosis [? ].

MCN is considered a pre-malignant lesion and surgical resection for all surgically fit candidates with MCNs is recommended by several international consensus guidelines [? ].

\subsection{Serous Cystic Neoplasms}

Serous cystic neoplasms (SCNs) represent less than $1 \%$ of all primary pancreatic lesions and about $30 \%$ of all cystic neoplasms of the pancreas [? ]. SCNs are benign cystic tumors of the pancreas and represent approximately $16 \%$ of resected PCLs. These tumors occur more frequently in women (75\%) at a mean age of 50 to 60 years [? ]. SCNs grow slowly and rare case reports document serous cystadenocarcinomas. As a consequence, surgery is usually reserved for symptomatic patients.

Serous cystadenoma (SCA) is usually solitary, without communication with the main pancreatic duct. Typically, it presents a multilocular honeycomb architecture due to the presence of multiple micro-cysts $(<20 \mathrm{~mm})$, thin wall and thin multiple septa orientated toward the center [? ]. Of note, oligo-macro-cystic appearance of SCA may be encountered. Macro-cystic type (25\%), especially the unilocular type, may be difficult to be differentiated from MCA [? ]. In contrast to MCNs, SCA may contain central, stellate calcification and in $15 \%$ of cases a central scar may be present [? ].

SCAs are typically hyper-enhancing on CEUS, since the septa are composed of abundant sub-epithelial micro- and macro-vessels and, especially when the cysts are small, they may mimic a solid lesion [? ]. CEUS improves the US characterization of SCA, showing the enhancement of the centrally oriented septa with better identification of the "honeycomb" multilocular architecture of the lesion [? ].

CEUS may be helpful not only in the differential diagnosis of SCA, but also in the long-term follow-up of these tumors, which can be conservatively managed in most cases.

\section{Non Neoplastic Cystic Lesions Pseudocyst}

Pseudocysts are defined as a collection of amylase-rich fluid that contains debris, blood, and inflammatory cells, and is surrounded by a fibrous wall with no epithelial lining [? ]. Pseudocysts are the most common pancreatic nonneoplastic cystic lesions and they occur after episodes of acute pancreatitis, or are superimposed on chronic pancreatitis due to alcoholic, biliary, or traumatic cause [? ]. Pseudocysts do not enhance at any phase with CEUS, even when heterogeneous on B-mode US [? ? ]. The reported sensitivity and 
specificity of CEUS in characterizing pseudocysts is up to 100\% [? ]. EFSUMB guidelines state that CEUS can be used to differentiate between cystic neoplasms and pseudocysts [? ].

\section{Chronic Pancreatitis}

Chronic pancreatitis $(\mathrm{CP})$ is characterized by fibrosis, destruction and distortion of the pancreatic ducts with loss of parenchyma. The most important diagnostic sign of chronic pancreatitis is the presence of calcifications and the dilatation (more than $3 \mathrm{~mm}$ ) or irregular course of the pancreatic duct [? ? ]. During the evolution of $\mathrm{CP}$, inflammatory masses can appear, a characteristic feature of pseudo-tumoral $\mathrm{CP}$. Differential diagnosis between this entity and pancreatic cancer is often difficult due to the similar imaging aspect: they, indeed, are both hypoechoic in conventional US [? ]. CEUS can improve the differential diagnosis between pseudo-tumoral CP and pancreatic adenocarcinoma. D'Onofrio et al. showed the hypoecho-genicity of ductal adenocarcinoma in all contrast-enhanced phases, due to its intense desmoplastic reaction with poor mean vascular density of the lesion, contrary to the enhancement in the early contrast-enhanced phase characteristic of the inflammatory mass (Figure ??) [? ].

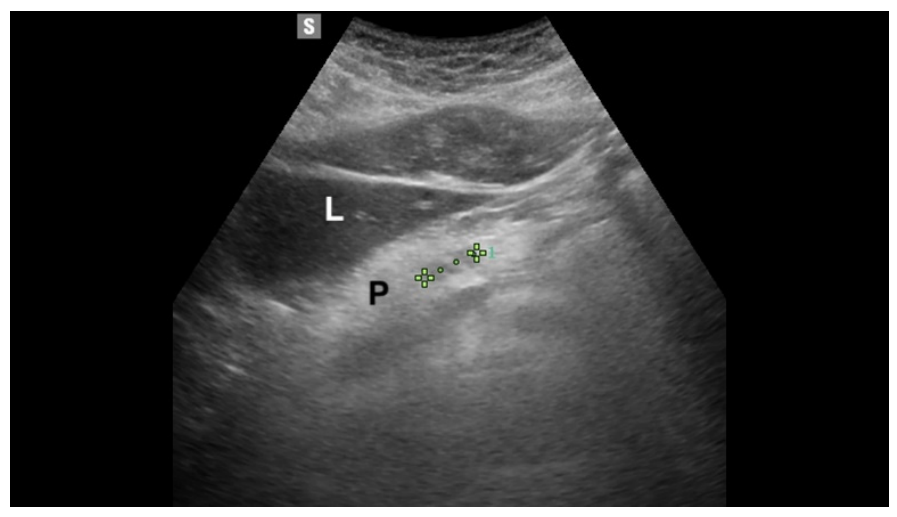

(A)

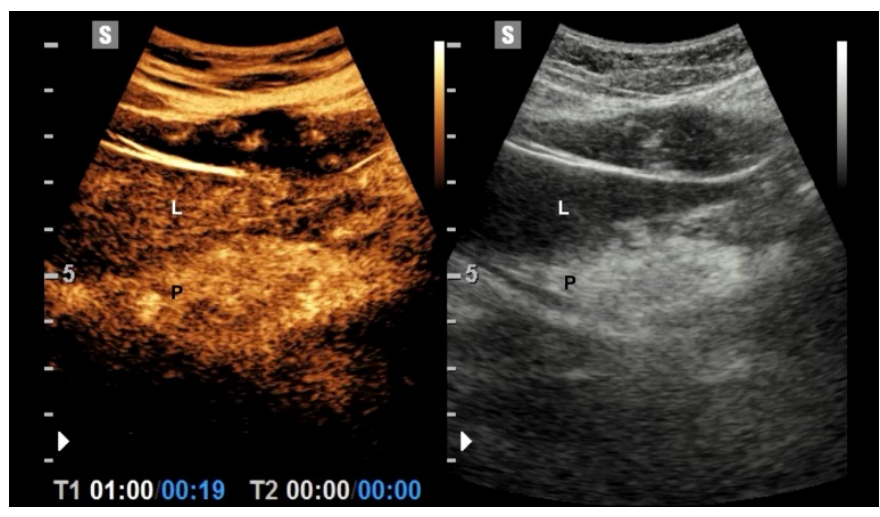

(B)

Figure 4. Focal autoimmune pancreatitis. (A) B mode Ultrasonography shows a $1.2 \mathrm{~cm}$ hypoechoic lesion (calipers) in the pancreatic body; (L: liver; P: Pancreas). (B) On CEUS, in the arterial phase (19 s after the injection of c.a.), the lesion is isoechoic in comparison with the adjacent pancreatic parenchyma.

The inflammatory origin of the lesion is therefore supported by the presence of parenchymal enhancement similar to that of the adjacent pancreas during the dynamic study, and the intensity of the enhancement is related to the length of the inflammatory process. However, in long-standing chronic inflammatory processes, inhomogeneous hypo-vascularization of the lesion may be observed, probably owing to the presence of a large amount of fibrosis, and differential diagnosis becomes more difficult [? ? ].

\section{Conclusions}

CEUS has been proved to be an accurate imaging method for evaluating differences in the vascularity of various pancreatic lesions and helpful in the differentiation between solid and cystic lesions. CEUS is a robust and safe technique which can allow an immediate characterization of the lesion or its follow-up.

Author Contributions: All authors contributed to this work as follow: study design T.V.B., P.A., A.T.; conceptualization P.A., A.R., A.T.; Methodology E.B., P.A.; Investigation T.V.B., A.R., writingoriginal draft preparation T.V.B., A.R., P.A., Review-Editing A.R., P.A., Supervision T.V.B., A.T. All authors have read and agreed to the published version of the manuscript.

Funding: This research received no external funding.

Conflicts of Interest: The authors declare no conflict of interest. 


\section{References}

1. Tedesco, G.; Sarno, A.; Rizzo, G.; Grecchi, A.; Testa, I.; Giannotti, G.; D’Onofrio, M. Clinical use of contrast-enhanced ultrasound beyond the liver: A focus on renal, splenic, and pancreatic applications. Ultrasonography 2019, 38, 278-288. [CrossRef] [PubMed]

2. Bartolotta, T.V.; Pinto, A.S.; Cannella, R.; Porrello, G.; Taravella, R.; Randazzo, A.; Taibbi, A. Focal liver lesions: Inter- and intraobserver agreement evaluation of 3D CEUS assisted volume measurement. Ultrasonography 2020. [CrossRef]

3. Bartolotta, T.V.; Terranova, M.C.; Gagliardo, C.; Taibbi, A. CEUS LI-RADS: A pictorial review. Insights Imaging 2020, 11, 9. [CrossRef] [PubMed]

4. Quaia, E. Microbubble ultrasound contrast agents: An update. Eur. Radiol. 2007, 17, 1995-2008. [CrossRef]

5. Piscaglia, F.; Bolondi, L.; Italian Society for Ultrasound in Medicine and Biology (SIUMB) Study Group on Ultrasound Contrast Agents. The safety of Sonovue ${ }^{\circledR}$ in abdominal applications: Retrospective analysis of 23188 investigations. Ultrasound Med. Biol. 2006, 32, 1369-1375. [CrossRef] [PubMed]

6. D’Onofrio, M.; Canestrini, S.; De Robertis, R.; Crosara, S.; Demozzi, E.; Ciaravino, V.; Mucelli, R.P.; Mirko, D.; Stefano, C.; Riccardoa, D.R.; et al. CEUS of the pancreas: Still research or the standard of care. Eur. J. Radiol. 2015, 84, 1644-1649. [CrossRef]

7. D’Onofrio, M.; Megibow, A.J.; Faccioli, N.; Malagò, R.; Capelli, P.; Falconi, M.; Mucelli, R.P. Comparison of Contrast-Enhanced Sonography and MRI in Displaying Anatomic Features of Cystic Pancreatic Masses. Am. J. Roentgenol. 2007, 189, 1435-1442. [CrossRef] [PubMed]

8. Sidhu, P.S.; Cantisani, V.; Dietrich, C.F.; Gilja, O.H.; Saftoiu, A.; Bartels, E.; Bertolotto, M.; Calliada, F.; Clevert, D.-A.; Cosgrove, D.; et al. The EFSUMB Guidelines and Recommendations for the Clinical Practice of Contrast-Enhanced Ultrasound (CEUS) in Non-Hepatic Applications: Update 2017 (Long Version). Ultraschall Med. Eur. J. Ultrasound 2018, 39, e2-e44. (In English) [CrossRef]

9. Globocan. Available online: https://gco.iarc.fr/today/data/factsheets/cancers/13-Pancreas-fact-sheet.pdf (accessed on 3 April 2021).

10. Low, G.; Panu, A.; Millo, N.; Leen, E. Multimodality Imaging of Neoplastic and Nonneoplastic Solid Lesions of the Pancreas. Radiographics 2011, 31, 993-1015. [CrossRef]

11. Bosman: WHO Classification of Tumours of the Digestive System, 4th ed.; World Health Organization: Geneva, Switzerland, 2010.

12. Wang, Y.; Yan, K.; Fan, Z.; Sun, L.; Wu, W.; Yang, W. Contrast-Enhanced Ultrasonography of Pancreatic Carcinoma: Correlation with Pathologic Findings. Ultrasound Med. Biol. 2016, 42, 891-898. [CrossRef]

13. D'Onofrio, M.; Barbi, E.; Dietrich, C.F.; Kitano, M.; Numata, K.; Sofuni, A.; Principe, F.; Gallotti, A.; Zamboni, G.A.; Mucelli, R.P. Pancreatic multicenter ultrasound study (PAMUS). Eur. J. Radiol. 2012, 81, 630-638. [CrossRef]

14. D'Onofrio, M.; Biagioli, E.; Gerardi, C.; Canestrini, S.; Rulli, E.; Crosara, S.; De Robertis, R.; Floriani, I. Diagnostic Performance of Contrast-Enhanced Ultrasound (CEUS) and Contrast-Enhanced Endoscopic Ultrasound (ECEUS) for the Differentiation of Pancreatic Lesions: A Systematic Review and Meta-Analysis. Ultraschall Med. Eur. J. Ultrasound 2014, 35, 515-521. [CrossRef]

15. D'Onofrio, M.; Crosara, S.; Signorini, M.; De Robertis, R.; Canestrini, S.; Principe, F.; Mucelli, R.P. Comparison between CT and CEUS in the Diagnosis of Pancreatic Adenocarcinoma. Ultraschall Med. Eur. J. Ultrasound 2013, 34, 377-381. [CrossRef] [PubMed]

16. Bartolotta, T.V.; Taibbi, A.; Picone, D.; Anastasi, A.; Midiri, M.; Lagalla, R. Detection of liver metastases in cancer patients with geographic fatty infiltration of the liver: The added value of contrast-enhanced sonography. Ultrasonography 2017, 36, 160-169. [CrossRef] [PubMed]

17. Park, S.J.; Jang, S.; Han, J.K.; Kim, H.; Kwon, W.; Jang, J.Y.; Lee, K.B.; Kim, H.; Lee, D.H. Preoperative assessment of the resectabil-ity of pancreatic ductal adenocarcinoma on CT according to the NCCN Guidelines focusing on SMA/SMV branch in-vasion. Eur. Radiol. 2021. [CrossRef]

18. Wei, Y.; Yu, X.-L.; Liang, P.; Cheng, Z.-G.; Han, Z.-Y.; Liu, F.-Y.; Yu, J. Guiding and Controlling Percutaneous Pancreas Biopsies with Contrast-Enhanced Ultrasound: Target Lesions Are Not Localized on B-Mode Ultrasound. Ultrasound Med. Biol. 2015, 41, 1561-1569. [CrossRef]

19. Tawada, K.; Yamaguchi, T.; Kobayashi, A.; Ishihara, T.; Sudo, K.; Nakamura, K.; Hara, T.; Denda, T.; Matsuyama, M.; Yokosuka, O. Changes in Tumor Vascularity Depicted by Contrast-Enhanced Ultraso-nography as a Predictor of Chemotherapeutic Effect in Patients With Unresectable Pancreatic Cancer. Pancreas 2009, 38, 30-35. [CrossRef]

20. Fraenkel, M.; Kim, M.; Faggiano, A.; Valk, G. Epidemiology of gastroenteropancreatic neuroendocrine tumours. Best Pract. Res. Clin. Gastroenterol. 2012, 26, 691-703. [CrossRef] [PubMed]

21. Öberg, K.; Eriksson, B. Endocrine tumours of the pancreas. Best Pract. Res. Clin. Gastroenterol. 2005, 19, 753-781. [CrossRef]

22. Orditura, M.; Petrillo, A.; Ventriglia, J.; Diana, A.; Laterza, M.M.; Fabozzi, A.; Savastano, B.; Franzese, E.; Conzo, G.; Santini, L.; et al. Pancreatic neuroendocrine tumors: Nosography, management and treatment. Int. J. Surg. 2016, 28 (Suppl. 1), S156-S162. [CrossRef]

23. Falconi, M.; Bartsch, D.K.; Eriksson, B.; Klöppel, G.; Lopes, J.M.; O'Connor, J.M.; Salazar, R.; Taal, B.G.; Vullierme, M.P.; O’Toole, D.; et al. ENETS Consensus Guidelines for the Management of Patients with Digestive Neuroendocrine Neoplasms of the Digestive System: Well-Differentiated Pancreatic Non-Functioning Tumors. Neuroendocrinology 2012, 95, 120-134. [CrossRef]

24. Abdelkader, A.; Hunt, B.; Hartley, C.P.; Panarelli, N.C.; Giorgadze, T. Cystic Lesions of the Pancreas: Differential Diagnosis and Cytologic-Histologic Correlation. Arch. Pathol. Lab. Med. 2020, 144, 47-61. [CrossRef]

25. Kim, Y.H.; Saini, S.; Sahani, D.; Hahn, P.F.; Mueller, P.R.; Auh, Y.H. Imaging diagnosis of cystic pancreatic lesions: Pseudocyst versus non pseudocyst. Radiographics 2005, 25, 671-685. [CrossRef] [PubMed] 
26. Freeny, P.C.; Saunders, M.D. Moving beyond Morphology: New Insights into the Characterization and Management of Cystic Pancreatic Lesions. Radiology 2014, 272, 345-363. [CrossRef] [PubMed]

27. Gaujoux, S.; Brennan, M.F.; Gonen, M.; D’Angelica, M.I.; De Matteo, R.; Fong, Y.; Schattner, M.; Di Maio, C.; Janakos, M.; Jarnagin, W.R.; et al. Cystic Lesions of the Pancreas: Changes in the Presentation and Management of 1,424 Patients at a Single Institution over a 15-Year Time Period. J. Am. Coll. Surg. 2011, 212, 590-600. [CrossRef]

28. Megibow, A.J.; Baker, M.E.; Morgan, D.E.; Kamel, I.R.; Sahani, D.V.; Newman, E.; Brugge, W.R.; Berland, L.L.; Pandharipande, P.V. Management of Incidental Pancreatic Cysts: A White Paper of the ACR Incidental Findings Committee. J. Am. Coll. Radiol. 2017, 14, 911-923. [CrossRef]

29. De Jong, K.; Nio, C.Y.; Hermans, J.J.; Dijkgraaf, M.G.; Gouma, D.J.; Van Eijck, C.H.; Van Heel, E.; Klass, G.; Fockens, P.; Bruno, M.J. High Prevalence of Pancreatic Cysts Detected by Screening Magnetic Resonance Imaging Examinations. Clin. Gastroenterol. Hepatol. 2010, 8, 806-811. [CrossRef]

30. Ip, I.K.; Mortele, K.J.; Prevedello, L.M.; Khorasani, R. Focal Cystic Pancreatic Lesions: Assessing Variation in Radiologists' Management Recommendations. Radiology 2011, 259, 136-141. [CrossRef]

31. Laffan, T.A.; Horton, K.M.; Klein, A.P.; Berlanstein, B.; Siegelman, S.S.; Kawamoto, S.; Johnson, P.T.; Fishman, E.K.; Hruban, R.H. Prevalence of Unsuspected Pancreatic Cysts on MDCT. AJR Am. J. Roentgenol. 2008, 191, 802-807. [CrossRef]

32. Yoon, J.G.; Smith, D.; Ojili, V.; Paspulati, R.M.; Ramaiya, N.H.; Tirumani, S.H. Pancreatic cystic neoplasms: A review of current recommendations for surveillance and management. Abdom. Radiol. 2021, 1-17. [CrossRef]

33. D'Onofrio, M.; Zamboni, G.; Faccioli, N.; Capelli, P.; Mucelli, R.P. Ultrasonography of the pancreas. 4. Contrast enhanced imaging. Abdom. Imaging 2007, 32, 171-181. [CrossRef]

34. Zhang, X.-M.; Mitchell, D.G.; Dohke, M.; Holland, G.A.; Parker, L. Pancreatic Cysts: Depiction on Single-Shot Fast Spin-Echo MR Images. Radiology 2002, 223, 547-553. [CrossRef]

35. Sahani, D.V.; Kadavigere, R.; Saokar, A.; Fernandez-del Castillo, C.; Brugge, W.R.; Hahn, P.F. Cystic pancreatic lesions: A sim-ple imaging-based classification system for guiding management. Radiographics 2005, 25, 1471-1484. [CrossRef]

36. Lewin, M.; Hoeffel, C.; Azizi, L.; Lacombe, C.; Monnier-Cholley, L.; Raynal, M.; Arrivé, L.; Tubiana, J.M. Imaging of incidental cystic lesions of the pancreas. J. Radiol. 2008, 89, 197-207. [CrossRef]

37. Zamboni, G.; Kloppel, G.; Hruban, R.H.; Longnecker, D.S.; Adler, G. Mucinous cystic neoplasms of the pancreas. World Health Organization classification of tumors. In Pathology and Genetics of Tumors of the Digestive System; Hamilton, S.R.A.L., Ed.; IARC Press: Lyon, Franch, 2000; pp. 237-240.

38. Procacci, C.; Megibow, A.J.; Carbognin, G.; Guarise, A.; Spoto, E.; Biasiutti, C.; Pistolesi, G.F. Intraductal Papillary Mucinous Tumor of the Pancreas: A Pictorial Essay. Radiographics 1999, 19, 1447-1463. [CrossRef] [PubMed]

39. Van Huijgevoort, N.C.M.; Del Chiaro, M.; Wolfgang, C.L.; Van Hooft, J.E.; Besselink, M.G. Diagnosis and management of pancreatic cystic neoplasms: Current evidence and guidelines. Nat. Rev. Gastroenterol. Hepatol. 2019, 16, 676-689. [CrossRef]

40. Zamboni, G.A.; Ambrosetti, M.C.; D’Onofrio, M.; Mucelli, R.P. Ultrasonography of the Pancreas. Radiol. Clin. N. Am. 2012, 50, 395-406. [CrossRef] [PubMed]

41. Tanaka, M.; Chari, S.; Adsay, V.; Fernandez-del Castillo, C.; Falconi, M.; Shimizu, M.; Yamaguchi, K.; Yamao, K.; Matsuno, S.; International Association of Pancreatology. International Consensus Guidelines for Management of Intraductal Papillary Mucinous Neoplasms and Mucinous Cystic Neoplasms of the Pancreas. Pancreatology 2006, 6, 17-32. [CrossRef] [PubMed]

42. Xu, M.; Xie, X.-Y.; Liu, G.-J.; Xu, H.-X.; Xu, Z.-F.; Huang, G.-L.; Chen, P.-F.; Luo, J.; Lu, M.-D. The application value of contrastenhanced ultrasound in the differential diagnosis of pancreatic solid-cystic lesions. Eur. J. Radiol. 2012, 81, 1432-1437. [CrossRef] [PubMed]

43. Scheiman, J.M.; Hwang, J.H.; Moayyedi, P. American Gastroenterological Association Technical Review on the Diagnosis and Management of Asymptomatic Neoplastic Pancreatic Cysts. Gastroenterology 2015, 148, 824-848.e22. [CrossRef]

44. Greer, J.B.; Ferrone, C.R. Spectrum and Classification of Cystic Neoplasms of the Pancreas. Surg. Oncol. Clin. N. Am. 2016, 25, 339-350. [CrossRef]

45. Crippa, S.; Salvia, R.; Warshaw, A.L.; Domínguez, I.; Bassi, C.; Falconi, M.; Thayer, S.P.; Zamboni, G.; Lauwers, G.Y.; MinoKenudson, M.; et al. Mucinous Cystic Neoplasm of the Pancreas is Not an Aggressive Entity: Lessons from 163 resected patients. Ann. Surg. 2008, 247, 571-579. [CrossRef]

46. Fan, Z.; Yan, K.; Wang, Y.; Qiu, J.; Wu, W.; Yang, L.; Chen, M. Application of Contrast-Enhanced Ultrasound in Cystic Pancreatic Lesions Using a Simplified Classification Diagnostic Criterion. BioMed Res. Int. 2015, 2015, 974621. [CrossRef] [PubMed]

47. Sun, Y.; Yang, S.; Qi, E.; Liu, F.; Zhou, F.; Lu, Y.; Liang, P.; Ye, H.; Yu, X. Comparative Diagnostic Evaluation with ContrastEnhanced Ultrasound, Computed Tomography and Magnetic Resonance Imaging in Patients with Pancreatic Cystic Neoplasms. Cancer Manag. Res. 2020, 12, 2889-2898. [CrossRef] [PubMed]

48. Sakorafas, G.H.; Smyrniotis, V.; Reid-Lombardo, K.M.; Sarr, M.G. Primary pancreatic cystic neoplasms revisited, part I: Se-rous cystic neoplasms. Surg. Oncol. 2011, 20, e84-e92. [CrossRef]

49. Khurana, B.; Mortele, K.J.; Glickman, J.; Silverman, S.G.; Ros, P.R. Macrocystic Serous Adenoma of the Pancreas: RadiologicPathologic Correlation. AJR Am. J. Roentgenol. 2003, 181, 119-123. [CrossRef]

50. Procacci, C.; Biasiutti, C.; Carbognin, G.; Accordini, S.; Bicego, E.; Guarise, A.; Spoto, E.; Andreis, I.A.; De Marco, R.; Megibow, A.J. Characterization of Cystic Tumors of the Pancreas: CT Accuracy. J. Comput. Assist. Tomogr. 1999, 23, 906-912. [CrossRef] [PubMed] 
51. Itoh, T.; Hirooka, Y.; Itoh, A.; Hashimoto, S.; Kawashima, H.; Hara, K.; Kanamori, A.; Ohmiya, N.; Niwa, Y.; Goto, H. Usefulness of contrast?enhanced trans-abdominal ultrasonography in the diagnosis of intraductal papillary mucinous tumors of the pancreas. Am. J. Gastroenterol. 2005, 100, 144-152. [CrossRef] [PubMed]

52. Procacci, C.; Biasiutti, C.; Carbognin, G.; Capelli, P.; El-Dalati, G.; Falconi, M.; Misiani, G.; Ghirardi, C.; Zamboni, G. Pancreatic neoplasms and tumor-like conditions. Eur. Radiol. 2001, 11 (Suppl. 2), S167-S192.

53. Niederau, C.; Grendell, J.H. Diagnosis of chronic pancreatitis. Gastroenterology 1985, 88, 1973-1995. [CrossRef]

54. Hessel, S.J.; Siegelman, S.S.; McNeil, B.J.; Sanders, R.; Adams, D.F.; Alderson, P.O.; Finberg, H.J.; Abrams, H.L. A prospective evaluation of computed tomography and ultrasound of the pancreas. Radiology 1982, 143, 129-133. [CrossRef] [PubMed]

55. van Gulik, T.M.; Reeders, J.W.; Bosma, A.; Moojen, T.M.; Smits, N.J.; Allema, J.H.; Rauws, E.A.; Offerhaus, G.J.A.; Obertop, H.; Gouma, D.J. Incidence and clinical findings of benign, inflammatory disease in patients resected for presumed pancreatic head cancer. Gastrointest. Endosc. 1997, 46, 417-423. [CrossRef]

56. D’Onofrio, M.; Zamboni, G.; Tognolini, A.; Malagò, R.; Faccioli, N.; Frulloni, L.; Mucelli, R.P. Mass-forming pancreatitis: Value of con-trast-enhanced ultrasonography. World J. Gastroenterol. 2006, 12, 4181-4284. [CrossRef] [PubMed]

57. Takeda, K.; Goto, H.; Hirooka, Y.; Itoh, A.; Hashimoto, S.; Niwa, K.; Hayakawa, T. Contrast-enhanced transabdominal ultrasonography in the diagnosis of pancreatic mass lesions. Acta Radiol. 2003, 44, 103-106. [CrossRef] [PubMed] 